\title{
EVALUASI PEMENUHAN STANDAR MINIMAL SARANA DAN PRASARANA PENDIDIKAN DASAR DI KOTA BANDUNG
}

\author{
Tjahyani Busono \\ Dosen Jurusan Pendidikan Teknik Arsitektur FPTK UPI
}

\begin{abstract}
ABSTRAK : Tujuan penelitian ini adalah untuk memperoleh gambaran kondisi sarana prasarana pendidikan dasar berdasarkan standar sarana dan prasarana sekolah/madrasah umum (Permendiknas 24 Tahun 2007). Hasil penelitian memberikan gambaran bahwa sebagian besar luas bangunan sekolah sudah sesuai dengan standar yang ditetapkan. Ruang kelas sebagai tempat kegiatan belajar mengajar yang utama pada sebagian besar sekolah sudah sangat memadai.Hanya masih dijumpai beberapa sekolah yang belum memiliki ruang guru, ruang kepala sekolah, ruang UKS, mushala, dan gudang yang representatif dalam rangka menunjang kegiatan belajar mengajar.Tetapi masih ada sekolah yang kurang memperhatikan fasilitas pendukung dan tidak secara berkala melaksanakan pemeliharaan bangunan tersebut.Bagi sekolah yang berada di pinggir jalan raya, masih belum dapat mengatasi kebisingan yang diakibatkan oleh lalulintas sehingga dapat mengganggu kegiatan belajar mengajar. Adanya sekolah yang berdekatan dengan pusat keramaian seperti pasar juga memerlukan perhatian untuk mengurangi terganggunya kegiatan belajar mengajar.
\end{abstract}

Kata Kunci : evaluasi, sekolah dasar, standar sarana prasarana.

ABSTRACT: This research was aimed to describe the condition of infrastructure facilitiesof basic education based on the standard of school facilities and infrastructure/public madrasah (Permendiknas no. 24 2007). The results illustrate that the vast majority of school buildingsare in accordance with the standards established. Classrooms a splaces of teaching and learning in most primary schools have been very adequate. Only still found some schools that do not have the staff room, principal room, UKS space, prayer room, and werehouse representative in order to support teaching and learning activities. But still there are schools that less attention and support facilities not regularly carry out maintenance of the building. For schools that are in the main street, still unable to overcome the noise caused by traffic so that it can interfere with teaching and learning activities. The existence of the school adjacent to the crowd as the market also require attention to reduce the disruption of teaching and learning activities.

Keywords: evaluation, elementaryschool, the standard infrastructure. 


\section{PENDAHULUAN}

Pembangunan pendidikan nasional ke depan didasarkan pada paradigma membangun manusia Indonesia seutuhnya, yang berfungsi sebagai subyek yang memiliki kapasitas untuk mengaktualisasikan potensi dan dimensi kemanusiaan secara optimal. Dimensi kemanusiaan itu mencakup tiga hal paling elementer, yaitu: (i) afektif yang tercermin pada kualitas keimanan dan ketakwaan, etika dan estetika, serta akhlak mulia dan budi pekerti luhur; (ii) kognitif yang tercermin pada kapasitas pikir dan daya intelektualitas untuk menggali ilmu pengetahuan dan mengembangkan serta menguasai teknologi; dan (iii) psikomotorik yang tercermin pada kemampuan mengembangkan keterampilan teknis dan kecakapan praktis.

Permasalahan dalam kualitas pendidikan tidak berdiri sendiri, tetapi terkait dalam satu sistem yang saling berpengaruh. Mutu keluaran dipengaruhi oleh mutu masukan dan mutu proses. Secara eksternal, komponen masukan pendidikan yang secara signifikan berpengaruh terhadap peningkatan mutu pendidikan meliputi: (1) ketersediaan pendidik dan tenaga kependidikan yang belum memadai baik secara kuantitas dan kualitas, maupun kesejahteraan pendidik yang belum memadai, (2) prasarana dan sarana belajar yang belum tersedia dan belum didayagunakan secara optimal, dan (3) biaya pendidikan yang belum memadai untuk menunjang mutu pembelajaran, serta (4) proses pembelajaran yang belum efisien dan efektif.

Pada aspek fisik, prasarana-sarana penunjang pendidikan belum sepenuhnya kondisinya memadai. Selain kondisi fasilitas yang demikian, juga banyak ruang belajar, dan sarana belajar lain seperti laboratorium, sarana olahraga yang rusak. Gambaran kondisi tersebut adalah sebagai berikut dari sekitar 865.258 ruang belajar (lokal) terdapat sekitar 500.818 lokal SD/MI (57,8\%) yang rusak ringan dan rusak berat. Sementara pada jenjang SMP dari sekitar 187.480 ruang belajar terdapat 31.198 lokal SMP/MTs (17,7\%) yang juga mengalami rusak ringan dan berat. Pada jenjang SM terdapat sekitar 13.777 lokal (15,6\%) yang rusak ringan dan rusak berat (Balitbang Depdiknas, 2003). 
Kondisi yang demikian, selain akan berpengaruh pada ketidaklayakan, ketidak nyamanan pada proses belajar mengajar, juga akan berdampak pada keengganan orangtua untuk menyekolahkan anaknya ke sekolah-sekolah tersebut.

Permasalahan penelitian ini dirumuskan dalam bentuk pertanyaan penelitian sebagai berikut:

1. Bagaimana gambaran hasil evaluasi kondisi sarana prasarana pendidikan Sekolah Dasar di Kota Bandung berdasarkan standar sarana dan prasarana sekolah/madrasah umum (Permendiknas 24 Tahun 2007) ?

2. Bagaimana bentuk rumusan rekomendasi kebijakan untuk meningkatkan kualitas sarana prasarana pendidikan dasar untuk mendukung perluasan akses pendidikan dasar di Kota Bandung?

Sedangkan tujuan penelitian ini adalah untuk memperoleh :

1. Gambaran kondisi sarana prasarana pendidikan dasar berdasarkan standar sarana dan prasarana sekolah/madrasah umum (Permendiknas 24 Tahun 2007).

2. Bentuk rumusan rekomendasi kebijakan untuk meningkatkan kualitas sarana prasarana pendidikan dasar untuk mendukung perluasan akses pendidikan dasar di Kota Bandung.

\section{METODE}

Studi ini harus dilaksanakan secara komprehensif dan proporsional meliputi semua aspek yang berhubungan dengan tingkat pemerataan dan mutu pendidikan di Kota Bandung. Dengan pendekatan semacam itu, maka dilakukan kombinasi metode penelitian yaitu secara kuantitatif dan kualitatif (Singarimbun \& Effendi, 1995; Creswell, 1994). Kombinasi model gabungan itu secara spesifik disebut oleh Creswell (1994) sebagai dominant-less dominant design. Metode kuantitatif digunakan sebagai metode utama penelitian, sedangkan metode kualitatif hanya sebagai pendukung.

Metode kuantitatif dilaksanakan dengan cara survei, yang menyajikan data secara deskriptif-eksplanasi. Berdasarkan hal ini penelitian tidak mencoba memanipulasi variabel, kecuali data tentang variabel-variabel tersebut dikumpulkan serta 
dianalisisberdasarkan data yang paling aktual, dan kemudian disusun untuk menggambarkan apa adanya.

Kekurangan penelitian yang sifatnya kuantitatif diusahakan ditekan sekecil mungkin dengan cara melakukan penelitian kualitatif. Dalam usaha memperoleh data yang bersifat kualitatif, metode observasi dilakukan dengan harapan unsur-unsur yang tidak diungkapkan oleh responden dalam komunikasi tatap muka dapat terjaring.

Jenis penelitian yang akan dilaksanakan termasuk penelitian evaluasi. Dalam hal yang khusus, penelitian evaluasi dapat dinyatan sebagai evaluasi, tetapi dalam hal lain juga dapat dinyatakan sebagai penelitian. Sebagai evaluasi berarti hal ini merupakan bagian dari proses pembuatan keputusan, yaitu untuk membandingkan suatu kejadian, kegiatan dan produk dengan standard dan program yang telah ditetapkan. Terdapat dua jenis dalam penelitian evaluasi yaitu: penelitian evaluasi formatif yang menekankan pada proses dan evaluasi sumatif yang menekankan pada produk (Kidder 1981).

Evaluasi berkaitan erat dengan pengukuran dan penilaian yang pada umumnya diartikan tidak berbeda (indifferent), walaupun pada hakekatnya berbeda satu dengan yang lain. Pengukuran (measurement) adalah proses membandingkan sesuatu melalui suatu kriteria baku (meter, kilogram, takaran dan sebagainya), pengukuran bersifat kuantitatif. Penilaian adalah suatu proses transformasi dari hasil pengukuran menjadi suatu nilai. Evaluasi meliputi kedua langkah di atas yakni mengukur dan menilai yang digunakan dalam rangka pengambilan keputusan.

T. Raka Joni di dalam Penelitian dan Pengembangan Pendidikan (1980) menyatakan bahwa beda antara penelitian dengan penilaian terletak pada tujuannya. Kalau penelitian pada dasarnya ditujukan untuk memperoleh pemahaman fenomena dalam arti seluas-luasnya, maka penilaian ditujukan untuk mengembil tindakan tertentu. Selanjutnya dikatakan bahwa penelitian terutama bersifat conclusionoriented sedangkan penilaian terutama bersifat decision-oriented, bahwa keputusankeputusan diambil berdasarkan data. Metode, langkah dan instrumen yang digunakan dalam penelitian dan penilaian adalah sama. 
Beberapa model penilaian/evaluasi program telah dikembangkan oleh para ahli untuk melaksanakan penilaian program. Pada bagian ini akan diuraikan dua model penilaian program yaitu model CIPP dan model Stake. Dalam penelitian ini model evaluasi yang digunakan adalah Model Stake.

Model Stake digambarkan dalam Description matriks berhubungan dengan tujuan dan akibat. Judgement berhubungan dengan standar (tolok ukur/kriteria) dan pertimbangan. Stake menegaskan ketika kita menimbang-nimbang dalam menilai suatu program pendidikan, kita tentu melakukan pembandingan relatif antara suatu program dengan program yang lainnya dan atau dengan pembanding absolut (suatu program dengan standar).

\section{HASIL DAN PEMBAHASAN}

\section{Tinjauan Umum Kota Bandung}

Kota Bandung dibentuk sebagai daerah otonom pada tanggal 1 April 1906, dan luas wilayah 1.922 ha.Pada tahun 1917, luasan kota Bandung menjadi 2.871 ha. Perluasan kota Bandung berturut-turut diadakan, masing-masing pada tahun 1942 menjadi 3.876 ha, pada tahun 1943 menjadi 4.117 ha, dan pada tahun 1945 menjadi 5.413 ha. Zaman negara Pasundan, tahun 1949, luasan menjadi 8.098 ha, dan pada tahun 1987 kota Bandung dimekarkan lagi menjadi 16.729,650 ha.

Kota Bandung terletak di wilayah Propinsi Jawa Barat dan merupakan Ibukota Propinsi. Kota Bandung terletak antara 107 $36^{\prime}$ Bujur Timur dan 6 $6^{\circ} 55^{\prime}$ Lintang Selatan. Secara administratif kota Bandung dibagi menjadi 6 (enam) wilayah yaitu wilayah Bojonegara, Cibeunying, Tegallega, Karees, Ujungberung, dan Gedebage.

Kota Bandung terletak pada ketinggian 791 meter di atas permukaan laut (dpl). Titik tertinggi terletak di daerah Utara dengan ketinggian 1.050 meter dan terendah di sebelah Selatan 675 meter di atas permukaan laut.

Tanah di kota Bandung dan sekitarnya adalah lapisan alluvial hasil letusan Gunung Tangkuban Perahu. Jenis tanah di bagian utara umumnya merupakan andosol, di bagian selatan serta bagian timur merupakan alluvial kelabu dengan bahan endapan liat.Di bagian tengah dan barat tersebar tanah andosol. 
Jumlah fasilitas pendidikan menurut jenjang sekolah di kota Bandung tahun 2004 tertera pada Tabel 1.

Tabel 1. Jumlah fasilitas pendidikan menurut jenjang sekolah di kota Bandung tahun 2004

\begin{tabular}{|c|l|c|c|c|}
\hline No. & \multicolumn{1}{|c|}{ Sekolah } & $\begin{array}{c}\text { Jumlah } \\
\text { sekolah }\end{array}$ & $\begin{array}{c}\text { Jumlah } \\
\text { guru }\end{array}$ & Jumlah murid \\
\hline 1 & Taman Kanak-kanak (TK) & 379 & 1.569 & 21.335 \\
\hline 2 & Sekolah Dasar (SD) & 923 & 11.135 & 446.477 \\
\hline 3 & Sekolah Luar Biasa & - & - & - \\
\hline 4 & $\begin{array}{l}\text { Sekolah Lanjutan Tingkat Pertama } \\
\text { (SLTP) }\end{array}$ & 207 & 5.417 & 99.729 \\
\hline 5 & Sekolah Menengah Atas (SMA) & 135 & 4.694 & 77.176 \\
\hline 6 & Sekolah Menengah Kejuruan (SMK) & 72 & 568 & 30.706 \\
\hline \multicolumn{2}{|r|}{ Jumlah } & 1.716 & 23.383 & 675.422 \\
\hline
\end{tabular}

\section{Deskripsi Kondisi Sarana Prasarana Sekolah Dasar}

Pada bagian ini akan diuraiakan mengenai kondisi sarana dan prasarana Sekolah Dasar yang menjadi sampel penelitian. Hal ini untuk memberikan gambaran umum mengenai kondisi sarana prasarana Sekolah Dasar tersebut yang akan dijadikan sebagai bahan untuk melaksanakan evaluasi pemenuhan standar sarana prasarana. Gambaran umum hasil evaluasi tersebut diuraikan pada bagian berikut.

Evaluasi pertama kali dilaksanakan terhadap jenis sekolah, pada penelitian ini dibatasi pada sekolah-sekolah negeri saja, jadi sekolah tersebut merupakan sekolah milik pemerintah. Status tanah tempat mendirikan bangunan sekolah masih memerlukan perhatian, karena masih ada sekolah dasar yang status tanahnya belum bersertifikat. Lokasi sekolah dasar sebagian besar berada di lingkungan perumahan dan ada sekolah dasar yang berada di pinggir jalan raya. Lokasi sebagian besar sekolah dasar yang diamati telah sesuai dengan Rencana Tata Ruang Wilayah (RTRW) yang ditetapkan pemerintah Kota Bandung.

Kegiatan evaluasi selanjutnya adalah pengukuran luas lahan yang dimiliki sekolah. Lahan yang tersedia dikelompokkan menjadi tiga, yaitu lahan untuk bangunan, lahan untuk lapangan olahraga/upacara, dan lahan untuk ruang terbuka hijau (taman). Luas lahan yang dimiliki oleh beberapa Sekolah Dasar masih belum 
memenuhi standar yang ditetapkan dalam Permendiknas Nomor 24 Tahun 2007 tentang Standar Sarana Prasarana Sekolah/Madrasah Umum. Masih cukup banyak sekolah yang tidak memiliki lapangan yang memadai untuk kegiatan olahraga atau upacara bendera, sehingga pelaksanaan olahraga seringkali dilaksanakan di luar kawasan sekolah. Yang memprihatinkan juga masih banyaknya sekolah yang tidak memiliki ruang terbuka hijau (taman) yang memadai.

Sebagai contoh Sekolah Dasar Negeri Antapani 2 memiliki lahan seluas kurang lebih $1.046 \mathrm{~m}^{2}$. Penggunaan lahan adalah sebagai berikut: (1) Lahan untuk bangunan 881 m² $^{2}$ (2) Lahan untuk lapangan olah raga/upacara $165 \mathrm{~m}^{2}$; dan (3) Lahan untuk taman/ruang terbuka hijau $15 \mathrm{~m}^{2}$.Gambaran pemanfaatan lahan SDN Antapani 2 tertera pada Gambar 1.

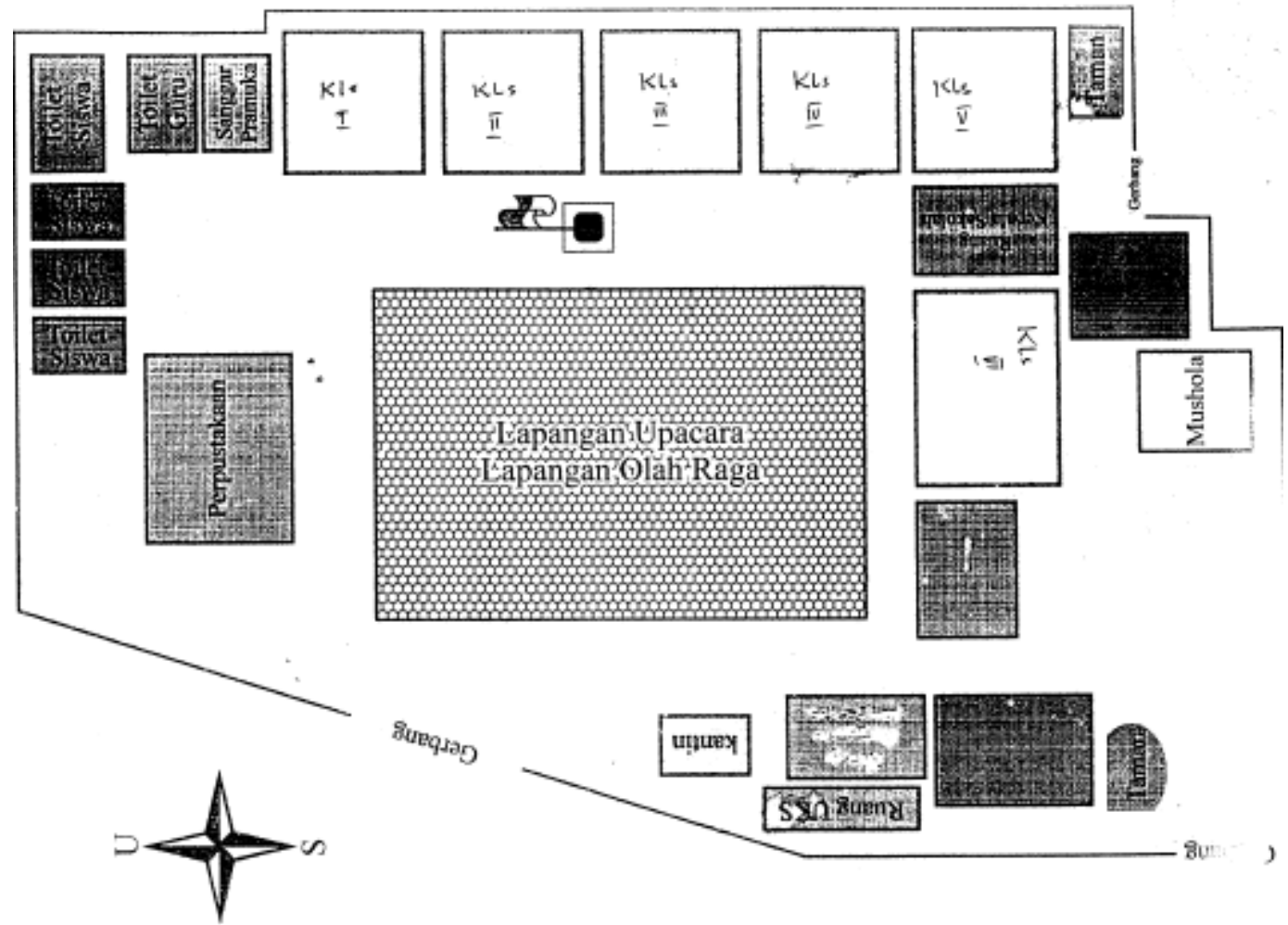

Gambar 1. Denah Penggunaan Lahan SDN Antapani 2

Evaluasi yang dilaksanakan berikutnya adalah observasi, studi dokumentasi dan wawancara untuk memperoleh data yang berkaitan dengan jumlah rombongan belajar, jumlah siswa pada masing-masing kelas, jumlah guru, dan jumlah karyawan. 
Gambaran umum hasil evaluasi tersebut menunjukkan bahwa jumlah rombongan belajar berkisar antara $6-12$ rombongan belajar. Jumlah guru yang mengajar pada sebagian besar sekolah dasar di Kota Bandung sudah cukup, hal ini terlihat dari jumlah guru yang selalu lebih tinggi dibandingkan dengan jumlah rombongan belajar. Rasio guru siswa juga sudah cukup baik, yaitu sekitar 1 : 30. Rata-rata sekolah dasar memiliki karyawan minimal 1 orang.

Kegiatan evaluasi dilanjutkan dengan mengobservasi kondisi bangunan sekolah. Sesuai dengan standar sarana prasarana untuk pendidikan dasar, sekolah dasar yang ideal harus memiliki ruang-ruang sebagai berikut: ruang kelas, ruang guru, ruang kepala sekolah, ruang perpustakaan, ruang laboratorium, ruang UKS, kamar mandi/WC, mushola, dan gudang. Evaluasi kondisi bangunan tersebut menggunakan kriteria seperti yang tertera pada tabel 2.

Tabel 2. Pedoman evaluasi kondisi bangunan

\begin{tabular}{|c|c|c|}
\hline Kategori kerusakan & Kerusakan secara umum & $\begin{array}{c}\text { Kondisi } \\
\text { Bangunan }\end{array}$ \\
\hline 0. Tidak rusak (T) & Tidak ada kerusakan & \\
\hline $\begin{array}{r}\text { I. Kerusakan ringan } \\
\text { non struktur (R) }\end{array}$ & $\begin{array}{l}\text { Retak halus pada plesteran ((lebar celah lebih } \\
\text { kecil dari 0,075 cm), serpihan plesteran } \\
\text { berjatuhan, mencakup luas yang terbatas. }\end{array}$ & Baik \\
\hline $\begin{array}{l}\text { II. Kerusakan ringan } \\
\text { struktur }(\mathrm{R})\end{array}$ & $\begin{array}{l}\text { Retak kecil pada dinding (lebar celah antara } \\
0,075 \text { hingga 0,6 cm), plesteran berjatuhan, } \\
\text { mencakup luas yang besar, kerusakan bagian- } \\
\text { bagian nonstruktur, seperti: lisplank, dsb., } \\
\text { kemampuan memikul beban tidak banyak } \\
\text { berkurang, laik fungsi }\end{array}$ & \\
\hline $\begin{array}{l}\text { III. Kerusakan sedang } \\
\text { Struktur (S) }\end{array}$ & $\begin{array}{l}\text { Retak besar pada dinding (lebar celah lebih } \\
\text { besar dari } 0,6 \mathrm{~cm} \text { ); retak menyebar luas di } \\
\text { banyak tempat, seperti: pada dinding pemikul } \\
\text { beban, kolom, cerobong miring dan runtuh. } \\
\text { Kemampuan struktur untuk memikul beban } \\
\text { sudah berkurang sebagian. }\end{array}$ & Sedang \\
\hline $\begin{array}{l}\text { IV. Kerusakan berat } \\
\text { struktur (B) }\end{array}$ & $\begin{array}{l}\text { Dinding pemikul beban terbelah dan runtuh, } \\
\text { kegagalan komponen-komponen pengikat } \\
\text { menyebabkan bangunan terpisah. Kira-kira } \\
\text { lebih dari } 40 \% \text { komponen struktur utama } \\
\text { mengalami kerusakan. Bangunan menjadi } \\
\text { sangat berbahaya. }\end{array}$ & Kurang \\
\hline V. Roboh & Sebagian besar atau seluruh bangunan roboh. & \\
\hline
\end{tabular}


Berdasarkan hasil evaluasi yang dilaksanakan sebagian besar ruang kelas sekolah dasar di Kota Bandung berada pada kondisi baik dan ada sebagian kecil yang mengalami kerusakan ringan. Ruang yang masih banyak mengalami kerusakan adalah kamar mandi/WC dan gudang, sedangkan ruang-ruang lainnya sebagian kondisinya cukup baik. Contoh hasil evaluasi kondisi bangunan ada pada Gambar 2.

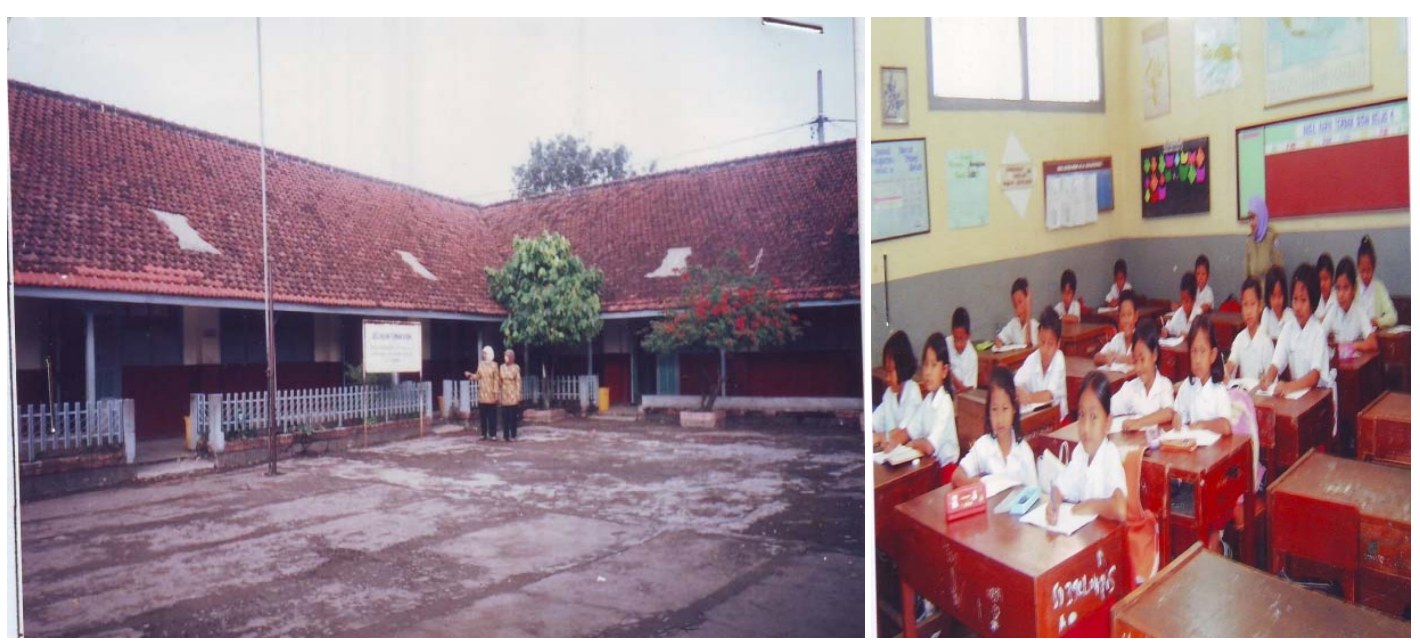

Gambar 2. Foto SDN Antapani 2

Evaluasi berikutnya adalah pemenuhan persyaratan keselamatan/keamanan, kesehatan, dan kenyamanan. Hasil evaluasi tersebut secara umum ada pada Tabel 3.

Tabel 3.Pemenuhan persyaratan keselamatan/keamanan, kesehatan, dan kenyamanan

\begin{tabular}{|c|l|c|}
\hline No & \multicolumn{1}{|c|}{ Indikator } & $\begin{array}{c}\text { Pemenuhan } \\
\text { persyaratan }\end{array}$ \\
\hline 1 & Memiliki konstruksi yang stabil dan kukuh & Baik \\
\hline 2 & $\begin{array}{l}\text { Dilengkapi sistem proteksi aktif dan atau pasif untuk } \\
\text { mencegah kebakaran }\end{array}$ & Kurang \\
\hline 3 & $\begin{array}{l}\text { Dilengkapi sistem proteksi aktif dan atau pasif untuk } \\
\text { mencegah petir }\end{array}$ & Sedang \\
\hline 4 & Fasilitas ventilasi udara/ventilasi udara & Baik \\
\hline 5 & Fasilitas pencahayaan & Baik \\
\hline 6 & Jaringan air bersih/air minum & Sedang \\
\hline 7 & Saluran air kotor/limbah & \\
\hline
\end{tabular}




\begin{tabular}{|c|l|c|}
\hline No & \multicolumn{1}{|c|}{ Indikator } & $\begin{array}{c}\text { Pemenuhan } \\
\text { persyaratan }\end{array}$ \\
\hline 8 & Saluran air hujan & Baik \\
\hline 9 & Pengelolaan sampah & Baik \\
\hline 10 & Bahan bangunan aman bagi kesehatan pengguna & Baik \\
\hline 11 & $\begin{array}{l}\text { Bangunan mampu meredam getaran dan kebisingan yang } \\
\text { dapat mengganggu PBM }\end{array}$ & Baik \\
\hline 12 & Setiap ruangan memiliki pengaturan penghawaan & Baik \\
\hline 13 & Setiap ruangan dilengkapi lampu penerangan & Baik \\
\hline 14 & Jalur Sirkulasi/aksesibilitas & Baik \\
\hline 15 & Koefisien dasar bangunan & Baik \\
\hline 16 & Dilengkapi instalasi listrik (minimum 900 Watt) & Kurang \\
\hline 17 & Dilengkapi jalur evakuasi bencana dan petunjuk yang jelas & Sedang \\
\hline 18 & Pemeliharaan bangunan & \\
\hline
\end{tabular}

\section{KESIMPULAN}

Berdasarkan hasil penelitian yang telah dilaksanakan, maka disarankan halhal sebagai berikut: (1) Kebutuhan lahan untuk aktivitas siswa dan pemenuhan standar sarana prasarana mutlak harus dipenuhi, sedangkan di Kota Bandung mengalami kesulitan untuk melaksanakan perluasan lahan, untuk memenuhi hal tersedut dapat dilaksanakan dengan melaksanakan pembangunan dengan menambah jumlah lantai bangunan dan melakukan penghapusan beberapa bangunan untuk dijadikan lahan tempat aktivitas siswa melaksanakan olahraga atau upacara serta untuk memenuhi kebutuhan ruang terbuka hijau (taman); (2) Pemenuhan ruang pendukung seperti ruang guru, UKS, mushola dapat dipenuhi dengan mengefektifkan ruang-ruang yang dimiliki dan menambah ruang baru. Bagi sekolah yang memiliki lahan sempit pemenuhan kebutuhan ruang tersebut harus diusahakan tidak mengambil lahan yang yang masih tersedia, tetapi melaksanakan pembangunan dengan menambah jumlah lantai sesuai dengan ketentuan yang berlaku.

\section{DAFTAR PUSTAKA}

Arikunto, S. (2006). Prosedur Penelitian Suatu Pendekatan Praktik. Jakarta: Rineka Cipta. 
Arikunto, S . (1988). Evaluasi Program. Jakarta, P2LPTK.

Borg, W.R. \& Gall, M.D. (2003).Educational Research an Introduction.Seventh Edition. New York : Longman.

Creswel, Jhon W. (1994). Research Design : Qualitative and Quantitative Aproach. London : Sage Publication.

Departemen Pendidikan Nasional. (2003). Undang-Undang Nomor 20 Tahun 2003 tentang Sistem Pendidikan Nasional. Jakarta, Biro Hukum dan Organisasi Depdiknas.

Departemen Pendidikan Nasional. (2007). Peraturan Menteri Pendidikan Nasional Republik Indonesia Nomor 24 Tahun 2007 Tentang Standar Sarana dan Prasarana Untuk Sekolah Dasar/Madrasah Ibtidaiyah (SD/MI), Sekolah Menengah Pertama/Madrasah Tsanawiyah (SMP/MTS), dan Sekolah Menengah Atas/Madrasah Aliyah (SMA/MA). Jakarta, Biro Hukum dan Organisasi Depdiknas.

Goodban \& Hayslett. (1979). Gambar Dan Perencanaan Arsitektur, Edisi 3. Jakarta: Erlangga.

Joni, TR (1980). Evaluasi Program. Jakarta, P2LPTK.

Mangunwijaya, Y.B. (1981). Pasal-Pasal Penghantar Fisika Bangunan. Jakarta: Gramedia.

Muhibbin, Syah. (2004). Psikologi Pendidikan dengan Pendekatan Baru. Bandung: PT. Remaja Rosdakarya.

Neufert , E. (1996). Data Arsitektur, Edisi 33, Jilid 1. Jakarta: Erlangga..

Satwiko,P. (2004). Fisika Bangunan 1. Jogjakarta : Andi.

Singarimbun dan Efendi. (1995). Penelitian Survei. Jakarta, Gramedia.

Sudjana, N. (1989). Metode Kegiatan Partisifatif. Bandung. Sinar Baru Algensindo.

Sudjana, N. dan Rivai, A. (2001). Teknologi Pengajaran. Bandung: Sinar Baru Algensindo.

Sugiyono. (2007). Metode Penelitian Pendidikan: Pendekatan Kuantitatif, Kualitatif dan $R \& D$. Bandung: Alfabeta.

Supriyadi, D. et al. (1996). Kurikulum dan Pembelajaran. Bandung: FIP IKIP Bandung.

Syamsuddin, A. (2007). Psikologi Kependidikan: Perangkat Sistem Pengajaran Modul. Bandung: PT. Remaja Rosdakarya

Usman, U. (2002). Menjadi Guru Profesional. Bandung: PT. Remaja Rosdakarya. 